\title{
Effect of naked oats and enzyme supplementation on egg yolk fatty acid composition and performance of hens
}

\author{
J.L. Sokó ${ }^{1.3}$, J. Niemiec ${ }^{2}$ and M. Fabijańska ${ }^{1}$ \\ Warsaw Agricultural University, \\ 'Department of Animal Nutrition and Feed Science. \\ ${ }^{2}$ Department of Poultry Science \\ Ciszewskiego 8, 02-786 Warsaw, Poland
}

\begin{abstract}
The experiment was conducted on $192 \mathrm{Hy}$-Line hens at the age of 25 weeks, divided into 3 groups, 64 hens per group. The birds were kept in individual cages. Three diets were prepared: diet 1 contained $450 \mathrm{~g} / \mathrm{kg}$ maize, diets 2 and $3,450 \mathrm{~g} / \mathrm{kg}$ naked oats, with (diet 3 ) or without (diet 2) $1 \mathrm{~g} / \mathrm{kg}$ of an enzymatic preparation with B-glucanase activity. Performance was recorded for 14 weeks, in the 5 th week 20 eggs were collected from each group and the fatty acid composition of yolk lipids was analysed.

The laying rate in the group fed the maize dict was $93 \%$, in both groups fed naked oat diets, $92 \%$, feed consumption did not differ among groups. The level of fatty acids and their ratio in egg yolks depended on the type of grain used. Yolks in groups fed diets with naked oats had more PUFA and a higher n-6/n-3 PUFA ratio than yolks in the group fed the maize dict. The supplementation of the naked oat diet with B-glucanase had no influence on performance or on the fatty acid profile in egg yolks.
\end{abstract}

KEY WORDS: laying hens, naked oats, ß-glucanase, performance, yolk fatty acids

\section{INTRODUCTION}

The naked oat contains less fibre and more energy than hulled oat. It is rich in B-glucans, which create a viscous solution in the gastrointestinal tract of poultry, interfering with nutrient digestion and absorption (Kosieradzka and Fabijańska, 2001). The anti-nutritional effect of B-glucans may be diminished by the addition of enzyme preparations containing B-glucanase to the diet (Boros, 1997). The naked oat contains more fat, more saturated fatty acids and less linoleic acid than maize (Kamińska et al., 2001).

The aim of the study was to evaluate the effect of complete replacement of naked oats for maize and supplementation of the naked oat diet with B-glucanase on the laying performance and fatty acid content in egg yolk.

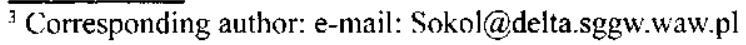




\section{MATERIAL AND METHODS}

The experiment was conducted on $192 \mathrm{Hy}$-Line laying hens at the age of 25 weeks. The birds were divided into 3 groups, 64 hens per group. The birds were kept in individual cages. Three diets were prepared: diet 1 contained $450 \mathrm{~g} / \mathrm{kg}$ maize, diets 2 and $3,450 \mathrm{~g} / \mathrm{kg}$ naked oats, with (diet 3) or without (diet 2) $1 \mathrm{~g} / \mathrm{kg}$ of the enzymatic preparation Avizyme 1200, containing B-glucanase activity. All diets contained $18 \%$ crude protein and $11.5 \mathrm{MJ} \mathrm{ME} / \mathrm{kg}$ and a similar content of lysine, sulphur amino acids, tryptophan, $\mathrm{Ca}, \mathrm{P}$ and $\mathrm{Na}$, which was adjusted to the requirement of the hens. The preliminary period lasted one week and the experiment was carried out for 14 weeks. The birds had free access to water and feed.

The laid eggs were collected daily, feed consumption was measured at weekly intervals. The laying rate over the period of 14 wecks was calculated. At the beginning of the fifth week of the experiment, twenty eggs from each group were collected, yolks were immediately separated and analysis of fatty acids was performed with the use of a HP-6890 gas chromatograph equipped with a $25 \mathrm{~m}$ long column with a diameter of $320 \mu \mathrm{m}$. The results were subjected to one-way analysis of variance (Harvey, 1985).

\section{RESULTS}

The laying rate in all groups was similar and amounted to $93 \%$ in the group fed the maize diet, and to about $92 \%$ in groups fed both naked oat diets, with or without B-glucanase. Also, the daily feed consumption in all groups was similar and equalled $135 \mathrm{~g} / \mathrm{bird}$.

The fatty acid profile in yolks differed, depending on the type of diet (Table 1). The level of saturated fatty acids (SFA) (C16:0 and C18:0) was significantly higher ( $\mathrm{P} \leq 0.05)$, while the level of monounsaturated acids (MUFA) $(\mathrm{C} 16: 1$ and $\mathrm{C}$ 18:1) was lower $(\mathrm{P} \leq 0.05)$ in groups that were fed both oat based diets than in the group fed the maize-based diet. Replacement of naked oats for maize caused an increase in the sum of polyunsaturated fatty acids (PUFA), mainly from the $\mathrm{n}-6$ family $(\mathrm{P} \leq 0.05)$ and an increase of the n-6/n-3 PUFA ratio in yolks (Table 1). Supplementation of the oat diet with B-glucanase did not affect the yolk fatty acid profile. 
TABLE 1

Fatty acid content in fresh yolks, in \% of total fatty acids

\begin{tabular}{|c|c|c|c|c|c|}
\hline \multirow{2}{*}{ Fatty acids } & & \multicolumn{4}{|c|}{ Group - dictary treatment } \\
\hline & & l-maize & 2- naked oats & 3-naked oats I enzyme & SFM \\
\hline \multirow[t]{2}{*}{ SFAC 16:0 } & & $25.84^{\mathrm{b}}$ & $26.90^{3}$ & $26.98^{i}$ & 0.21 \\
\hline & $C: 8: 0$ & $12.93^{b}$ & $13.19^{\mathrm{a}}$ & $13.30^{\mathrm{a}}$ & 0.32 \\
\hline \multirow[t]{2}{*}{ MLFA } & C.I6:I & $3.49^{3}$ & $1.97^{\mathrm{b}}$ & $1.91^{\mathrm{b}}$ & 0.10 \\
\hline & $C: 18: 1$ & $35.05^{\lrcorner}$ & $33.59^{\mathrm{b}}$ & $33.66^{\mathrm{h}}$ & 0.66 \\
\hline \multirow[t]{2}{*}{ PUFA n-3 } & $\mathrm{Cl} 8: 3$ & $0.2 \mathrm{I}^{\mathrm{\prime}}$ & $0.18^{b}$ & $0.14^{c}$ & 0.01 \\
\hline & $\mathrm{C} 22: 6$ & $2.64^{\prime \prime}$ & $2.05^{b}$ & $2.07^{\mathrm{b}}$ & 0.08 \\
\hline \multirow[t]{3}{*}{ PUFA n-6 } & C.18:2 & $13.86^{\mathrm{h}}$ & $16.70^{\mathrm{a}}$ & $16.38^{\mathrm{a}}$ & 0.09 \\
\hline & $\mathrm{C} 20: 3$ & $5.85^{\prime \prime}$ & $5.26^{\mathrm{h}}$ & $5.43^{\mathrm{b}}$ & 0.01 \\
\hline & $\mathrm{C} 20: 4$ & $0.15^{\mathrm{b}}$ & $0.17^{a}$ & $0.14^{b}$ & 0.01 \\
\hline$\Sigma$ SFA & & $38.77^{\mathrm{b}}$ & $40.09^{a}$ & $40.28^{a}$ & 0.50 \\
\hline$\Sigma$ MUFA & & $38.54^{\mathrm{a}}$ & $35.56^{\mathrm{b}}$ & $35.57^{\mathrm{b}}$ & 0.74 \\
\hline$\Sigma$ PUFA & & $22.71^{\mathrm{b}}$ & $24.36^{a}$ & $24.16^{\circ}$ & 0.26 \\
\hline Including: & $\sum n-3$ & $2.85^{\mathrm{a}}$ & $2.23^{\circ}$ & $2.21^{\mathrm{b}}$ & 0.08 \\
\hline & $\Sigma n-6$ & $19.86^{\mathrm{h}}$ & $22.13^{a}$ & $21.95^{\mathrm{a}}$ & 0.18 \\
\hline$n-6 / n-3$ & & 7 & 10 & 10 & \\
\hline
\end{tabular}

a. b.c means in rows marked with different letters differ significantly at $\mathrm{P} \leq 0.05$

SFA - saturated fatty acids, MUFA - monounsaturated fatty acids

PUFA - polyunsaturated fatty acids

\section{DISCUSSION}

The laying performance in all groups was good and was not affected by either the type of cereal in the diet or by the supplementation of the naked oat diet with B-glucanase. Kamińska et al. (2001) also reported that the laying rates in hens fed diets with maize or naked oats were similar and averaged $88 \%$ during nine months of an experiment. The lack of a positive effect of the enzymatic preparation indicated that 6-month-old laying hens are not as sensitive to oat $\beta$-glucans as broiler chickens (Kosicradzka, 1999; Kosicradzka and Fabijańska, 2001).

In the study of Kamińska et al. (2001) replacing naked oats for maize did not have a significant effect on the fatty acid profile of yolk lipids, while in the present study the fatty acid profile of egg yolks from both groups fed diets with naked oats was similar, but differed from that in the group fed the maize-based diet. The eggs from hens fed the naked oat diet had less MUFA and more SFA and PUFA than eggs from hens fed the maize diet. In the fat of both maize and naked oats, $\alpha$-linolenic acid amounted to only about $1 \%$ of total FA (Kaminska et al., 2001). Also in the present study yolk lipids, independent of the type of dietary cereal, were poor in that acid but contained over $2 \%$ of docosahexaenoic acid (DHA). It seems that hens use all available $\alpha$-linolenic acid for synthesis 
of DHA, which is necessary for normal embryo development. The proportion of $n-6 / n-3 P U F A$ was about 7 in eggs from hens fed the maize diet and increased to 10 in both groups fed naked oats. Both were within approved limits for human foods (Koreleski et al., 1998).

\section{CONCLUSIONS}

The naked oal may replace maize in diets for laying hens. Supplementing such dicts with an enzyme preparation containing ß-glucanase activity is not necessary.

\section{REFERENCES}

Boros D., 1997. Dictary fibre in poultry leeding (in Polish). Proceedings of Conference "Dietary Fibre - Chemical Composition and Biological Activity". Radzików (Poland), pp. 141-155

Harvey W.R., 1985. User's Guide for LSMLMW. Mixed model least-squares and maximum likelihood computer program. Ohio State University

Kamińska B.Z., Gąsior R., Skraba B., 2001. Modification of polyunsaturated fatty acid contents in yolk lipids using various cereals and blended animal fat in hens' diets. I. Anim. Feed Sci. 10, Suppl. 2, 255-260

Koreleski J., Kuchta M., Bykowski P., Sieradzka A., 1998. Vegetable-fish meal concentrates applied in leeding of the commercial laying hens (in Polish). Rocz. Nauk. 7oot. 25, 137-151

Kosicradzka I., 1999. Evaluation of the possibilitics of employing Polish naked oat grain in feeding of monogastric animals (in Polish). PhD Thesis, Warsaw Agricultural University Press. Warszawa (Poland)

Kosieradzka I., Fabijańska M., 2001, Effect of beta-glucans of naked oal on its energetic value for broiler chicks (in Polish). Ann. Warsaw Agr. Lniv., Anim. Sci., Special Number, pp. 238-245

\section{STRESZCZENIE}

Wplyw owsa nagiego i dodatku enzymu na skład kwasów tłuszczowych w źóltku jaj i wydạiność nieśną kur

Doświadczenic przeprowadzono na 192 kurach $\mathrm{Hy}$-Line w wieku 25 tygodni, podzielonych na 3 grupy po $64 \mathrm{w}$ grupic. Ptaki trzymano w indywidualnych klatkach. Przygotowano 3 dicty: dieta 1 zawierała $450 \mathrm{~g} / \mathrm{kg}$ kukurydzy, diety 2 i $3450 \mathrm{~g} / \mathrm{kg}$ owsa nagiego, bez dodatku (dicta 2) lub $<$ dodatkiem $1 \mathrm{~g} / \mathrm{kg}$ (dicta 3) preparalu enzymatycznego zawierajacego B-glukanaze. Przez 14 tygodni micrzono wydajność nieśnł oraz spożycic paszy. w 5 tygodniu w 20 jajach $z$ każdej grupy oznacrono skład kwasów thuszczowych w żółtkach.

Nieśnosic w grupie zyy wionej dietą z kukurydzą wynosiła $93 \%$. w obydwóch grupach żywionych dietami $z$ owsem nagim $92 \%$. Spozycie paszy nie rờzniło się miẹdzy grupami. Żółtka w grupach żywionych dictami $z$ owsem nagim zawierały wiçcej PUFA, a stosunek n-6/n-3 PUFA byl $w$ nich wyższy niż. w żółtkach jaj z grupy żywionej dietą z kukurydzą. Dodatck ß-glukanazy do diety 7. owsem nagim nie miał wpływu na nieśność ani na profil kwasów tłuszczowych w żóttkach jaj. 